\title{
New Product Development in high-tech startups - a conceptual framework
}

\author{
Rozwój nowych produktów w startupach technologicznych \\ — przegląd koncepcji
}

\author{
dr Ewa Sońta-Drączkowska \\ Szkoła Główna Handlowa w Warszawie, Kolegium Zarządzania i Finansów, Katedra Zarządzania Projektami \\ ORCID: 0000-0002-3061-4455 \\ esonta@sgh.waw.pl
}

\begin{abstract}
New product development (NPD) is a key value creating process in a high-tech startup. This article discusses the relevance of the traditional approaches to NPD and assesses their applicability to a newly founded high-techventure. Further, recent concepts to innovative venture creation were reviewed: design thinking, lean startup and agile project management. Based on the analysis an integrated framework for high-tech startup NPD has been proposed. This study is based on an extensive literature review and systematic comparison of the concepts discussed in the current entrepreneurship, new product development and project management literature.
\end{abstract}

Keywords

New product development, high-tech startups, design thinking, lean startup, agile project management

Rozwój nowych produktów (NPD) to kluczowy proces tworzenia wartości w startupach technologicznych. W artykule omówiono znaczenie tradycyjnych podejść do rozwoju nowych produktów i oceniono je pod kątem przydatności dla nowo utworzonych startupów technologicznych. Ponadto dokonano przeglądu innych koncepcji innowacji i tworzenia nowych przedsięwzięć: podejścia projektowego, lean startupu oraz zwinnego zarządzania projektami. Na podstawie analizy zaproponowano zintegrowane podejście do rozwoju nowych produktów, które może mieć zastosowanie w kontekście startupów technologicznych. Artykuł ma charakter przeglądowy i powstał na podstawie analizy oraz systematycznego porównania najnowszych koncepcji dyskutowanych w literaturze przedmiotu. Opracowanie integruje wątki dyskusji z dziedziny przedsiębiorczości, rozwoju nowych produktów i zarządzania projektami.

\section{Slowa kluczowe}

Rozwój nowych produktów, startupy technologiczne, podejście projektowe, lean startup, zwinne zarządzanie projektami

JEL: M13; O32

Str. $30-37$

\section{References}

Alam, I. (2006). Removing the fuzziness from the fuzzy front-end of service innovations through customer interactions. Industrial Marketing Management, 35(4), 468-480. https://doi.org/10.1016/j.indmarman.2005.04.004

Agile Alliance. (2001). Manifesto for Agile Software Development. Retrieved from https://www.agilealliance.org/ agile101/the-agile-manifesto/

Beckman, S. L. \& Barry, M. (2007). Innovation as a learning process: Embedding design thinking. California Management Review, 50(1), 25-56. https://doi.org/10.2307/41166415

Bernstein, M. \& Linsky M. (2016). Leading change through adaptive design. Stanford Social Innovation Review, (Winter), $49-54$.

Blank, S. (2007). The Four Steps to the Epiphany. Pescadero: K\&S Ranch.

Blank, S. \& Dorf, B. (2012). The startup owner's manual: The step-by-step guide for building a great company. BookBaby. 
Bloch, P. (2011). Product design and marketing: Reflections after fifteen years. Journal of Product Innovation Management, 28, 378-380. https://doi.org/10.1111/j.1540-5885.2011.00805.x

Bosch, J., Olsson, H. H., Björk, J., \& Ljungblad, J. (2013). The early stage software startup development model: A framework for operationalizing lean principles in software startups. In Lean Enterprise Software and Systems (pp. 115). Springer, Berlin, Heidelberg. https://doi.org/10.1007/978-3-642-44930-7_1

Buganza, T., Gerst, M., \& Verganti, R. (2010). Adoption of NPD flexibility practices in new technology-based firms. European Journal of Innovation Management, 13(1), 62-80. https://doi.org/10.1108/14601061011013230

Casson, M. \& Wadeson, N. (2007). The discovery of opportunities: Extending the economic theory of the entrepreneur. Small Business Economics, 28(4), 285-300. https://doi.org/10.1007/s11187-006-9037-7

Conforto, E. C., Amaral, D. C., da Silva, S. L., Di Felippo, A., \& Kamikawachi, D. S. L. (2016). The agility construct on project management theory. International Journal of Project Management, 34(4), 660-674. https://doi.org/ 10.1016/j.ijproman.2016.01.007

Conforto, E. C. \& Amaral, D. C. (2016). Agile project management and stage-gate model: A hybrid framework for technology-based companies. Journal of Engineering and Technology Management, 40, 1-14. https://doi.org/ 10.1016/j.jengtecman.2016.02.003

Cooper, R. G. (1990). Stage-gate systems: A new tool for managing new products. Business Horizons, 33(3), 44-54. https://doi.org/10.1016/0007-6813(90)90040-I

Cooper, R. G. (1994). Third-generation new product processes. Journal of Product Innovation Management: An International Publication of the Production Development \& Management Association, 11(1), 3-14. https://doi.org/ 10.1016/0737-6782(94)90115-5

Cooper, R. G. (2008). Perspective: The Stage-Gate ${ }^{\circledR}$ idea-to-launch process: Update, what's new, and NexGen systems. Journal of Product Innovation Management, 25(3), 213-232. https://doi.org/10.1111/j.1540-5885.2008.00296.x

Cooper, R. G. (2014). What's next? After stage-gate. Research-Technology Management, 57(1), 20-31. https://doi.org/ $10.5437 / 08956308 X 5606963$

Dean, B.V. (1996). The project-management approach in the "systematic management" of innovative start-up firms. Journal of Business Venturing, 1(2), 149-160. https://doi.org/10.1016/0883-9026(86)90011-X

Eppinger, S. D. (2001). Innovation at the speed of information. Harvard Business Review, 79(1), 149-158.

Frederiksen, D. L. \& Brem, A. (2017). How do entrepreneurs think they create value? A scientific reflection of Eric Ries' Lean Startup approach. International Entrepreneurship and Management Journal, 13(1), 169-189. https://doi.org/ 10.1007/s11365-016-0411-x

Gartner, Ch. \& Ludwig R. (2015). Design-Thinking im Projektmanagement. Zeitschrift fur Organization, (04), $255-261$.

Gonzalez, W. (2014). Applying agile project management to predevelopment stages of innovation. International Journal of Innovation and Technology Management, 11(04). https://doi.org/10.1142/S0219877014500205

Highsmith, J. (2009). Agile Project Management: Creating Innovative Products. Pearson Education.

Jetter, A., Albar, F., \& Sperry, R. C. (2016). Project Management in Product Development. Insights from the Literature and Cases in High Tech. Project Management Institute.

Lane, M., Fitzgerald, B., \& Agerfalk, P. (2012). The Influence of new product development on Scrum practices. Proceedings from Researching Agile Development of Information Systems (RAISE 2012). London.

Leithold, N., Haase, H., \& Lautenschläger, A. (2015). Stage-Gate ${ }^{\circledR}$ for SMEs: A qualitative study in Germany. European Journal of Innovation Management, 18(2), 130-149. https://doi.org/10.1108/EJIM-07-2014-0070

Lenfle, S. (2008). Exploration and project management. International Journal of Project Management, 26(5), 469-478. https://doi.org/ 10.1016/j.ijproman.2008.05.017

Lenfle, S. \& Loch, C. (2010). Lost roots: How project management came to emphasize control over flexibility and novelty. California Management Review, 53(1), 32-55. https://doi.org/10.1525/cmr.2010.53.1.32

Liedtka, J. (2015). Perspective: Linking design thinking with innovation outcomes through cognitive bias reduction. Journal of Product Innovation Management, 32(6), 925-938. https://doi.org/10.1111/jpim.12163

Lockwood, T. (Ed.) (2009). Design Thinking: Integrating Innovation, Customer Experience, and Brand Value. New York: Allworth Press.

Martin, R. (2009). The Design of Business: Why design thinking is the next competitive advantage. Boston: Harvard Business Press.

Murphy, A. \& Ledwith, A. (2007). Project management tools and techniques in high-technology SMEs. Management Research News, 30(2), 153-166. https://doi.org/10.1108/01409170710722973

Pease, J. F., Dean, J. H., \& Van Bossuyt, D. L. (2014). Lean design for developing world: making design decision through the use of validated learning techniques in the developing world. Proceedings from International Mechanical Engineering Technical Conferences. https://doi.org/10.1115/IMECE2014-36612

Pons, D. (2008). Project management for new product development. Project Management Journal, 39(2), 82-97. https://doi.org/10.1002/pmj.20052 
Project Management Institute. (2017). Guide to the Project Management Body of Knowledge (PMBoK) Guide - Sixth Edition. Pennsylvania, Newton Square.

Reid, S. E. \& De Brentani, U. (2004). The fuzzy front end of new product development for discontinuous innovations: A theoretical model. Journal of Product Innovation Management, 21(3), 170-184. https://doi.org/10.1111/j.07376782.2004.00068.x

Ries, E. (2011). The Lean Startup: How today's entrepreneurs use continuous innovation to create radically successful businesses. Crown Books.

Rostek, K. \& Skala, A. (2017). Differentiating criteria and segmentation of Polish startup companies. Problemy Zarządzania, (1, t. 1). https://doi.org/10.7172/1644-9584.65.12

Sarasvathy, S. D. (2001). Causation and effectuation: Toward a theoretical shift from economic inevitability to entrepreneurial contingency. Academy of Management Review, 26(2), 243-263. https://doi.org/10.5465/amr. 2001.4378020

Schwaber, K. (1995). Scrum Development Process. Proceedings from OOPSLA'95 Workshop on Business Object Design and Implementation. Austin.

Shenhar, A. J. \& Dvir, D. (2007). Project management research: The challenge and opportunity. Project Management Journal, 38(2), 93-99. https://doi.org/10.1177/875697280703800210

Smith, K. (2005). Measuring innovation. In J. Fagerberg, D. Mowery, \& R. Nelson (Eds.), The Oxford Handbook of Innovation (chapter 6). Oxford: Oxford University Press.

Spencer, A. S. \& Kirchhoff, B.A. (2006). Schumpeter and new technology based firms: Towards a framework for how NTBFs cause creative destruction. International Entrepreneurship and Management Journal, 2(2), 145-156. https://doi.org/10.1007/s11365-006-8681-3

Takeuchi, H. \& Nonaka, I. (1986). The New New Product Development Game. Harvard Business Review, (January).

Tschimmel, K. (2012). Design Thinking as an effective Toolkit for Innovation. Proceedings from ISPIM Conference Proceedings. The International Society for Professional Innovation Management (ISPIM).

York, J. L. \& Danes, J. E. (2014). Customer development, innovation, and decision-making biases in the lean startup. Journal of Small Business Strategy, 24(2), 21-40. 